\title{
INHIBITION OF GELATINASE ACTIVITY OF MMP-2 AND MMP-9 BY EXTRACTS OF Bauhinia ungulata $\mathrm{L}$.
}

\author{
INIBIÇÃO DA ATIVIDADE GELATINOLÍTICA DE MMP-2 E MMP-9 A PARTIR DE \\ EXTRATOS DE Bauhinia ungulata L.
}

\section{Kamilla Monteiro dos SANTOS ${ }^{1}$; Damiana Antonia de FáTIMA NUNES ${ }^{2}$; Izabela Natália de FARIA, GOMES ${ }^{2}$; Saulo Luis da SILVA ${ }^{3}$; Rosy IaraMaciel de Azambuja RIBEIRO ${ }^{4}$}

1. Mestre em Biotecnologia pela Universidade Federal de São João Del Rei - UFSJ , Divinópolis, MG, Brasil; 2. Discentes do curso de Bioquímica - UFSJ, Divinópolis, MG, Brasil; 3. Professor, Doutor, UFSJ, Ouro Branco, MG, Brasil; 4. Professora, Doutora, UFSJ, Divinópolis, MG, Brasil. rosyiara@gmail.com

\begin{abstract}
Metastasis is responsible for the majority of cancer-related deaths. Tumour invasion and metastasis result from processes that include the proteolytic degradation of the extracellular matrix adjacent to the tumour. The matrix metalloproteinases (MMPs), particularly MMP-2 and MMP-9, have prognostic influence in human cancers after they cleave the main structural components of the basal membrane. These actions make MMPs an attractive target for cancer and metastasis studies. This study evaluated the inhibitory potency of extracts of Bauhinia ungulata L. (BU) on the gelatinolytic activity of MMP-2 and -9 and recognized the group of secondary compounds responsible for this property. The zymographic analysis of the BU stem revealed that the ethyl acetate partition (D) caused a higher inhibition of MMP2 and MMP-9. The phytochemical study of D showed the presence of steroids, tannins, and coumarins and the significant presence of alkaloids and flavonoids. The phytochemical study of the fractions obtained through the column chromatography of partition D revealed a significant presence of flavonoids and alkaloids in the fractions that showed better inhibition of the gelatinolytic activity of MMPs. In conclusion, these results suggest that the stem fraction of BU has the potential to inhibit MMP-2 and MMP-9 and should be used in studies on the recognition of active biomolecules.
\end{abstract}

KEYWORDS: Metalloproteinase, Phytochemical Study, Medicinal Plant, Zymogram, Pata de vaca.

\section{INTRODUCTION}

Matrix metalloproteinases (MMPs) are calcium- and zinc-dependent proteases that are believed to be responsible for the degradation of the extracellular matrix of tissues (NAGASE et al., 2006). Within the family of human MMPs, the matrix metalloproteinase 2 (MMP-2) (gelatinase A, $72 \mathrm{kDa}$ ) and matrix metalloproteinase 9 (MMP-9) (gelatinase B, $92 \mathrm{kDa}$ ) cleave, among other components, type IV collagen and gelatin, which are the main structural components of the basal membrane (REIS et al., 2012). With the exception of membrane-type MMPs, these enzymes are secreted as latent pro-enzymes and are usually regulated by endogenous tissue inhibitors of the matrix metalloproteinase (TIMPs) (WALTER et al., 2005). MMPs are present mainly in tissues with high metabolic activity, where they play a vital role in many physiological and pathological processes, including embryogenesis, tissue remodelling, angiogenesis, wound healing, and metastasis (MOTT; WERB, 2004).

Several studies have demonstrated the prognostic influence of MMPs in human cancers due to the association of higher expression levels of these proteins with increased tumour aggressiveness. However, this aggressiveness may be associated with a lower activity of TIMPs in the tissues (CHAUDHARY et al., 2010). Therefore, the inhibition of the proliferation and invasion mediated by gelatinases by extracts of plants may be the key to the prevention of the metastasis of neoplastic cells (LONGATTI et al., 2011).

The genus Bauhinia is popularly known in Brazil as "Pata-de-Vaca" and is widely used in traditional medicine as antidiabetic and antioxidant agents (FERNANDES et al., 2012). In India, flower buds, flowers, stems, stem barks, leaves, seeds, and roots of the several species of this genus are used as antidiabetic agents and for the treatment of other diseases (e.g., as antipyretic, astringent, tonic, antileprotic, and antitumour agents and for skin wound healing) in the Ayurvedic system of medicine (BODAKHE; RAM, 2007). The bark has also been documented for the cure of dysmenorrhea, menorrhagia, tuberculosis, and asthma and possesses hepatoprotective, anthelmintic, and antidiabetic activities (BODAKHE; RAM, 2007).

Although several studies have shown the properties of extracts of Bauhinia, the groups of compounds that are responsible for these properties have not been elucidated (FERNANDES et al., 2012). The objective of the present study was to 
evaluate the inhibitory potential of extracts of Bauhinia ungulata L. (BU) on the gelatinolytic activity of MMP-2 and MMP-9 and to identify the group of secondary compounds responsible for this property.

\section{MATERIAL AND METHODS}

\section{Chemicals}

All of the solvents and reagents were purchased from Sigma-Aldrich (USA).

\section{Plant materials}

Samples of the stem of the Bauhinia ungulata L. (BU) species were collected in May 2011 from a tree localized in Jovelino Rabelo street in Divinópolis (-20 $8^{\circ}$ 46.07", $\left.-44^{\circ} 5^{\prime} 3^{\prime} 1.86^{\prime \prime}\right)$, Minas Gerais, Brazil. The plant was identified (Teacher Doctor Guilherme Araújo Lacerda, CRBio 44480/04-D) and deposited in the Herbarium of the Department of Botany, Federal University of Minas Gerais, under the following code: BHCB161588.

Powdered stem from BU (100 g) was extracted by maceration in $500 \mathrm{~mL}$ of $70 \%$ hydroalcoholic solution for seven days to obtain the Crude Extract (CE), which was filtered and then lyophilized (Liobras ${ }^{\circledR}$ equipment, model $\mathrm{K}$ 105). The $\mathrm{CE}$ was dissolved in ethanol/water (7:3) and successively extracted with hexane $\left(\mathrm{C}_{6} \mathrm{H}_{14}\right)$, chloroform $\left(\mathrm{CHCl}_{3}\right)$, and ethyl acetate $\left(\mathrm{C}_{4} \mathrm{H}_{8} \mathrm{O}_{2}\right)$ to yield the following partitions: hydroalcoholic (A), hexane (B), chloroform (C), and ethyl acetate (D), respectively. The partitions were also lyophilized. The CE and the lyophilized partitions were subjected to zymographic analyses, and the extracts with the best results were subjected to column chromatography (silica gel 60) using solvents with increasing polarity (hexane, chloroform, ethyl acetate, methanol, and water). Through constant dripping, the fractions were collected in vials with a final volume of $50 \mathrm{~mL}$. All of the fractions were monitored by thin layer chromatography (TLC) and grouped according to their phytochemical profiles.

\section{Phytochemical study}

Phytochemical tests to detect the presence of secondary metabolites were performed according to Matos (1988) and Wagner and Bladt (2001) and following the methodologies described by Longatti et al. (2011), Barbosa et al. (2008), Silva (2008), and Sena Filho et al. (2006). These tests were based on visual observations of colour modifications and/or precipitate formation after the addition of specific reagents.

\section{Zymography}

The proteolytic activity of MMP-2 and MMP-9 was measured by gelatin zymography following a method adapted from that described by Ribeiro et al. (2010). In all of the tests, $5 \mu \mathrm{L}$ of each extract $(0.09 \mathrm{~g} / \mathrm{mL}$ in DMSO) was added to a well of a gel containing 1.5 $\mu \mathrm{L}$ of MMP-2 and MMP-9 (Sigma-Aldrich Chemie, M9445 and M8945, respectively, at a concentration of $1800 \mathrm{ng} / \mathrm{mL}$ in buffer SDS $2.5 \mathrm{~g} \%$ and saccharose $1 \mathrm{~g} \%$ ). The same quantity of MMPs was used as the standard, and this represented $100 \%$ of the active enzymes. Electrophoresis (BioRad Protean II) was conducted under reducing conditions (0.025 M TRIS, $0.192 \mathrm{M}$ glycine, and $0.1 \%$ SDS, $\mathrm{pH}$ 8.5) at a constant voltage of $70 \mathrm{~V}$ for $4 \mathrm{~h}$ at $4^{\circ} \mathrm{C}$. After electrophoresis, the gels were washed for $1 \mathrm{~h}$ with Triton X-100 (2.5 $\mathrm{g} \%)$ to remove SDS and then submerged under stirring conditions in activation buffer $(0.05 \mathrm{M}$ TRIS-HCl and $0.6 \mathrm{~g} \% \mathrm{CaCl}_{2}, \mathrm{pH} 8.0$ ) for $16 \mathrm{~h}$ at room temperature. The gels were stained $(0.25 \%$ Coomassie blue R-250, $45 \%$ methanol, and $10 \%$ acetic acid) for $1 \mathrm{~h}$ and destained (30\% ethanol and $10 \%$ acetic acid) for $1 \mathrm{~h}$.

Digital images of the gels were obtained using the Lpix Image ${ }^{\circledR}$ program (Loccus Biotecnology $y^{\circledR}$ ), and the white area (activity of MMPs) was quantified using the Axion Vizion ${ }^{\circledR}$ software (Release 4.8.6; 6-2010). The results are expressed as the percentage of inhibition of gelatinolytic activity caused by the extracts.

\section{Statistical analyses}

All of the zymograms were performed in duplicate, and the statistical analysis was based on Student's t test with $\mathrm{p}<0.05$.

\section{RESULTS AND DISCUSSION}

The phytochemical study (Table 1) of extract $\mathrm{D}$ showed the presence of steroids, tannins, and coumarins and the significant presence of alkaloids and flavonoids. The presence of saponins was not observed. The results of the secondary compounds found in this study are consistent with studies that have demonstrated the presence of flavonoids, such as quercetin (ALVES et al., 2011), proanthocyanidins, leucoanthocyanidins, triterpenes, steroids, and several other flavonoid compounds not yet identified in extracts of Bauhinia (BIANCO; SANTOS, 2010; MARQUES et al., 2012). Flavonoids are secondary metabolites with various medical functions, such as the prevention and slowing down of the carcinogenic process (CIMINO 
et al., 2012; DILIPKUMAR et al., 2012). Furthermore, previous studies have shown the inhibition of MMPs by polyphenolic compounds (ADHAMI et al., 2003; VAID et al., 2011). However, there are numerous types of flavonoids, many of which have unknown function and structure. Alkaloids also have a wide range of pharmacological properties, and studies have shown the putative antiprotozoal, antiviral, antitumoural, and inhibitory activities of acetylcholinesterase and their apoptotic effects (OSORIO et al., 2008; ANDRADE et al., 2012). Berberine, a natural isoquinoline alkaloid derived from Berberis species, has been reported to exhibit anti-cancer effects by the downregulation of MMP-9 expression (JANTOVA et al., 2003). Topotecan, another alkaloid, inhibits cancer cell migration by downregulating MMPs (MMP-2 and MMP-9) (LIN et al., 2009).

Table 01. Phytochemical study of extracts from the stem of BU.

\begin{tabular}{|c|c|c|c|c|c|c|}
\hline Extract & Steroids & Flavonoids & Saponins & Tannins & Allcaloids & Coumnins \\
\hline A & - & + & $\cdot$ & + & ++ & + \\
\hline B & + & - & - & - & + & - \\
\hline C & + & + & - & - & + & - \\
\hline D & + & $H$ & - & + & ++ & $H$ \\
\hline FR1 & - & + & - & - & + & + \\
\hline FR2 & - & + & - & - & ++ & - \\
\hline FR6 & - & + & - & - & ++ & - \\
\hline FR? & - & + & - & - & ++ & - \\
\hline FR8 & - & $H+$ & - & - & ++ & + \\
\hline$F R 12$ & - & + & - & - & ++ & - \\
\hline FR 3 & - & + & - & - & + & - \\
\hline FR1 4 & + & $H$ & - & - & + & + \\
\hline FR1 6 & + & + & - & - & ++ & - \\
\hline
\end{tabular}

A (hydroalcoholic partition), B (hexane partition), C (chloroform partition), D (ethyl acetate partition), FR1, FR2, FR6, FR7, FR8, FR12, FR13, FR14, and FR16 (chromatographic column fractions obtained from partition D). "-" (absence); "+”", “++", and "+++" (colour or precipitate is more intense compared to that of the other samples).

In a previous study, we found that the crude hydroethanolic extracts from all parts of BU showed inhibition of MMP-2 and MMP-9, and the crude extract of the stem showed the best inhibition results $(81.02 \%$ and $88.27 \%$, respectively). The lyophilization of the $\mathrm{CE}$ of the stems resulted in a yield of $3.0187 \mathrm{~g}$.

The zymographic analysis of the partitions of the stems of BU revealed that partition D caused a higher inhibition of MMP-2 and MMP-9 (Figure 1). The hydroalcoholic partition (A) also showed a significant inhibitory effect, and its fractionation will be analysed in future studies.

The column chromatography of partition D resulted in the collection of 74 fractions, and the phytochemical studies grouped these into 16 fractions. The analysis of their zymograms revealed that a higher inhibition of MMPs was obtained by fractions FR1, FR2, FR6, FR7, FR8, FR12, FR13, FR14, and FR16 (Figure 2).

It is known that neoplastic diseases are characterized by an imbalance between MMPs and their regulators that leads to an excess of degradative activity, which is assumed to be linked to the invasive character of tumour cells (WALLARD et al., 2006). The expression of MMP9 and MMP-2 has been implicated in the development and progression of many neoplasms, such as prostate, colorectal, and lung cancer (REIS et al., 2012). Mantena et al. (2005) showed that green tea polyphenols are promising as anticarcinogenic agents because these compounds prevent the development of solar UV radiationinduced skin cancer and reduce the expression of MMP-9 and MMP-2. The inhibition caused by fractions FR6 (99.98\% of MMP-9), FR7 (100\% of 
MMP-2 and MMP-9), FR12, FR13, and FR14 (92\%, 99\%, and $97 \%$ of MMP-2, respectively) is sufficient for these fractions to be further analysed in tumour proliferation inhibition studies.

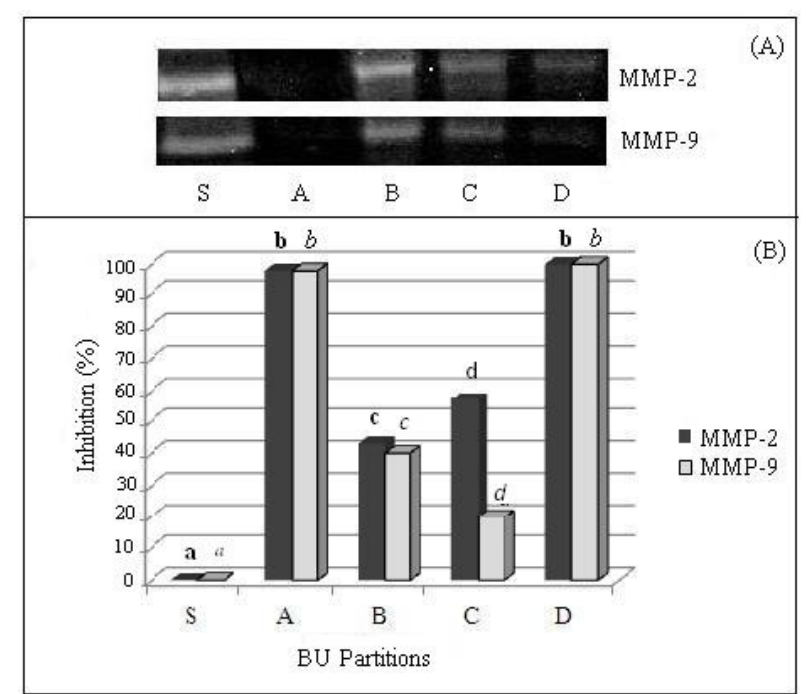

Figure 1. Inhibition of MMP-2 and MMP-9 by the hydroalcoholic partition (A), hexane partition (B), chloroform partition (C), and ethyl acetate partition (D); MMP-2 and MMP-9 free extracts (S) was used as the standard. The statistical analysis was based on Student's t test, and the letters indicate a significant difference between the samples with a $\mathrm{p}$ value of less than 0.05 . The bold letters represent the comparisons of the activities of the extracts on MMP-2, and the italic letters indicate the comparisons of the activities of the samples on MMP-9.

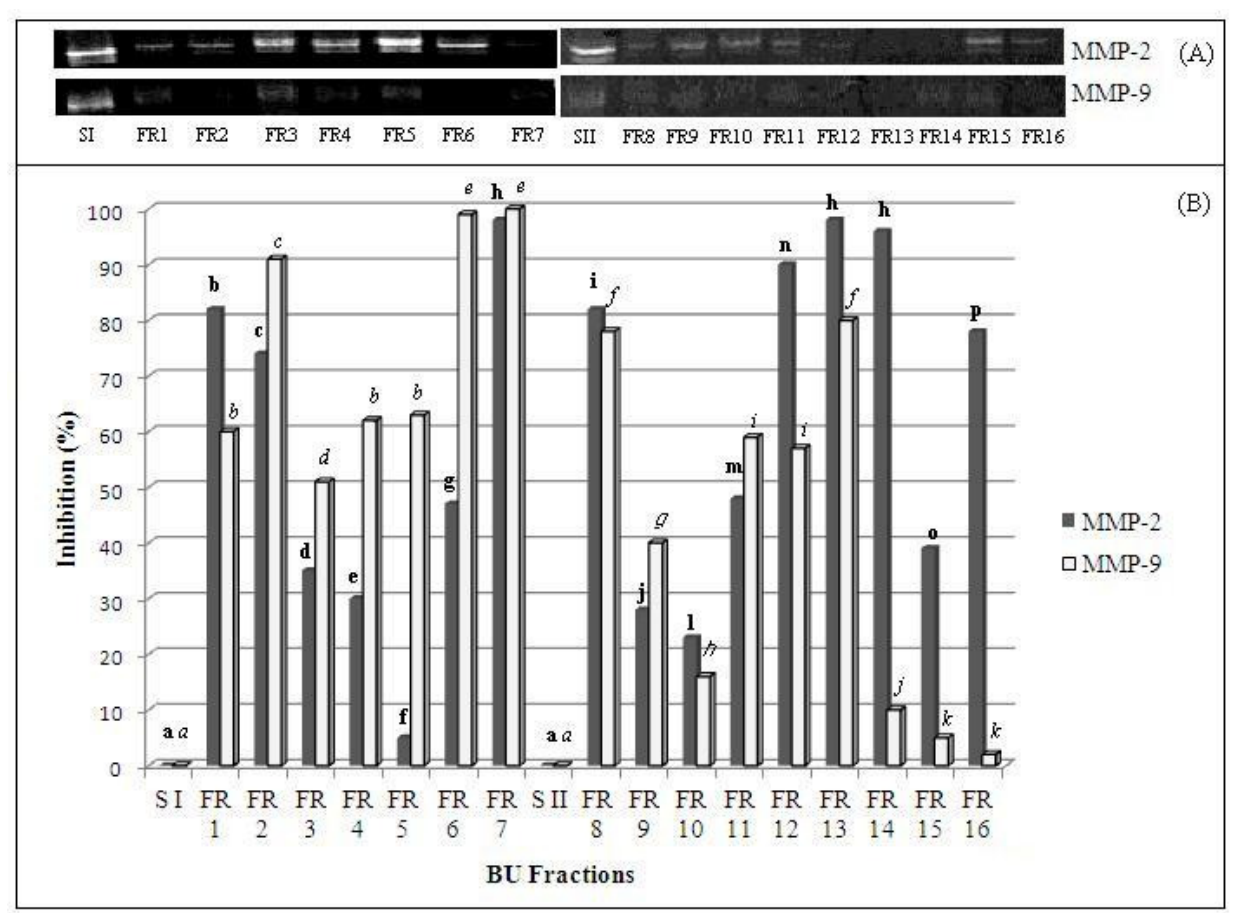

Figure 2. Inhibition of MMP-2 and MMP-9 by fractions (FR) of the BU compared with the standards (SI was used for fractions FR1 to FR7, and SII was used for fractions FR8 to FR16). The statistical analysis was based on Student's $t$ test, and the letters indicate a significant difference between the samples with a $\mathrm{p}$ value of less than 0.05 . The bold letters represent the comparisons of the activities of the extracts on MMP-2, and the italic letters correspond to the comparisons of the activities of the samples on MMP-9. 
The high number of extracts that exhibited inhibitory activity against MMPs, even after chromatographic fractionation, and the differences between the inhibition of MMP-2 and MMP-9 showed by some extracts suggest that several biomolecules may be responsible for the inhibition of these proteases.

The phytochemical study of these fractions revealed the significant presence of flavonoids and alkaloids, as in partition D. However, although they exhibited inhibitory activity against MMPs, some of the fractions did not reveal the presence of tannins and coumarins, which suggests that these secondary compounds are not responsible for the inhibition of the proteases studied.

In conclusion, extract D showed high and satisfactory inhibition of the gelatinolytic activity of
MMPs, indicating that it has the potential to be used in further studies for the recognition of active biomolecules. According to the results of the phytochemical studies of the fractions, the inhibition of the gelatinolytic activity of MMPs is due to a group of flavonoids and/or alkaloids. Future research, both in vitro and in vivo, will be conducted on the partitions of ethyl acetate from the stem of Bauhinia ungulata to isolate and identify compounds or molecules responsible for the properties demonstrated in the present study.

\section{ACKNOWLEDGEMENTS}

This work was supported by grants from FAPEMIG and CAPES.

RESUMO: A metástase é a responsável pela maioria das mortes relacionadas ao câncer. Tanto a invasão tumoral quanto a metástase resultam de processos que incluem a degradação proteolítica da matriz extracelular adjacente ao tumor. As metaloproteinases de matriz (MMPs), especialmente as MMP-2 e MMP-9, têm influência direta no prognóstico dos diversos tipos de câncer humano, pois clivam os principais componentes estruturais da membrana basal. Estas ações fazem das MMPs alvos atraentes para estudos envolvendo câncer e metástase. Este trabalho teve como objetivo avaliar o potencial inibidor dos extratos de Bauhinia ungulata L. (BU) sobre a atividade gelatinolítica das MMP-2 e 9 e reconhecer o grupo de compostos secundários responsáveis por esta propriedade. Análises por zimograma do ramo de BU revelaram que a partição de acetato de etila (D) causou maior inibição de MMP-2 e MMP-9. O estudo fitoquímico de D mostrou a presença de esteróides, taninos e cumarinas e a presença significativa de alcaloides e flavonoides. As frações da coluna cromatográfica da partição D e seus estudos fitoquímicos revelaram uma grande presença de flavonoides e alcaloides nas frações que apresentaram maior inibição da atividade gelatinolítica de MMPs. Em conclusão, estes resultados sugerem que frações do ramo de BU têm o potencial inibidor de MMP-2 e MMP-9 e devem ser utilizadas em estudos envolvendo o reconhecimento de biomoléculas ativas.

vaca.

PALAVRAS-CHAVE: Metaloproteinases. Estudo. Fitoquímico. Plantas. Medicinais. Zimograma. Pata de

\section{REFERENCES}

ADHAMI, V. M.; AHMAD, N.; MUKHTAR, H. Molecular targets for green tea in prostate cancer prevention. Journal of Nutrition, Rockville Pike, v. 133, n. 7, p. 2417-2424, jul. 2003.

ALVES, M. M. P.; ANA, M. S.; PEREIRA, P. S.; FRANÇA, S. C.; BERTONI, B. W. Caracterização química qualitativa de tinturas e extratos secos de plantas medicinais do Cerrado por cromatografia em camada delgada comparativa. Scientia Plena, São Crsitóvão, v. 7, n. 12, p. 1-8, dez. 2011.

ANDRADE, J. P.; PIGNI, N. B.; CLAVERIA, L. T.; BERKOV, S. L.; CODINA, C.; FRANCESC, V.; BATISDA, J. Bioactive alkaloid extracts from Narcissus broussonetii: Mass spectral studies. Journal of Pharmaceutical and Biomedical Analysis, Arlington, v. 70, p. 13-25, nov. 2012.

http://dx.doi.org/10.1016/j.jpba.2012.05.009

BARBOSA, W. L. R.; PINTO, L. A. N.; QUIGNARD, E.; VIEIRA, J. M. S.; SILVA JUNIOR, J. O. C.; ALBUQUERQUE, S. Arrabidaea chica (HBK) Verlot: phytochemical approach, antifungal and trypanocidal activities. Brasilian Journal Pharmacognosy, João Pessoa, v. 18, n. 4, p. 544-548, dec. 2008. 
BIANCO, E. M.; SANTOS, C. I. D. Propriedades antioxidantes de folhas e caule de Bauhinia microstachya (Raddi) J. F. Macbr. Brazilian Journal of Biosciences, Porto Alegre, v. 8, n. 3, p. 238-241, jul. 2010.

BODAKHE, S. H.; RAM, A. Hepatoprotective properties of Bauhinia variegata bark extract. Yakugaku Zasshi, Tokyo, v. 127, n. 9, p. 1503-1507, jun. 2007. http://dx.doi.org/10.1248/yakushi.127.1503

CHAUDHARY, A. K.; SINGH, M.; BHARTI, A. C.; ASOTRA, K.; SUNDARAM, S.; MEHROTRA, R. Genetic polymorphisms of matrix metalloproteinases and their inhibitors in potentially malignant and malignant lesions of the head and neck. Journal of Biomedical Science, Taiwan, v. 17, n. 1, p. 1-10, feb. 2010.

CIMINO, S.; SORTINO, G.; FAVILLA, V. C. T.; MADONIA, M.; SANSALONE, S.; RUSSO, G. I.; MORGIA, G. Polyphenols: Key issues involved in chemoprevention of prostate cancer oxidative. Medicine and Cellular Longevity, New York, v. 1, n. 1, p. 1-8, mar. 2012. http://dx.doi.org/10.1155/2012/632959

DILIPKUMAR, P.; SUBHAM, B.; ASHOKE, K. G. Dietary-induced cancer prevention: An expanding research arena of emerging diet related to healthcare system. Journal of Advanced Pharmaceutical Technology \& Research, Mumbai, v. 3, n. 1, p. 16-24, mar. 2012.

FERNANDES, A. J. D.; FERREIRA, M. R. A.; RANDAU, K. P.; SOUZA, T. P.; SOARES, L. A. L. Total Flavonoids Content in the Raw Material and Aqueous Extractives from Bauhinia monandra Kurz (Caesalpiniaceae). The Scientific World Journal, New York, v. 2012, n. 2012, p. 1-7, apr. 2012.

JANTOVA, S.; CIPAK, L. M. Effect of berberine on proliferation, cell cycle and apoptosis in HeLa and L1210 cells. National Journal of Physiology, Pharmacy and Pharmacology, Dallas, v. 55, n. 8, p. 1143-1149, aug. 2003. http://dx.doi.org/10.1211/002235703322277186

LIN, S. S.; SUN, L.; ZHANG, Y. K.; ZHAO, R. P.; LIANG, W. L.; YUAN, S. T.; ZHANG, L. Y. Topotecan inhibits cancer cell migration by down-regulation of chemokine $\mathrm{CC}$ motif receptor 7 and matrix metalloproteinases. Acta Pharmacologica Sinica, Shangai, v. 30, n. 5, p. 628-636, may. 2009.

LONGATTI, T. R.; CENZI, G.; LIMA, L. A. R. S.; OLIVEIRA, R. J. S.; OLIVEIRA, V. N.; SILVA, S. L.; RIBEIRO, R. I. M. A. Inhibition of gelatinases by vegetable extracts of the species Tapirira guianensis (Stick Pigeon). British Journal of Pharmaceutical Research, Houstoun, v. 1, n. 4, p. 133-140, jun. 2011.

MANTENA, S. K.; MEERAN, S. M.; ELMETS, C. A.; KATIYAR, S. K. Orally administered green tea polyphenols prevent ultraviolet radiation induced skin cancer in mice through activation of cytotoxic $\mathrm{T}$ cells and inhibition of angiogenesis in tumors. American Society for Nutrition, Rockville Pike, v. 135, n. 12, p. 2871-2877, dec. 2005.

MARQUES, G. S. L.; MAGALY, A. M.; PEIXOTO, M. S.; MONTEIRO, R. P. M.; LEÃO, W. F.; XAVIER, H. S.; SOARES, L. A. L.; ROLIM-NETO, P. J. Phytochemical characterization and physical chemistry from the leaves of Bauhinia forficate Link collected in two brazilian regions. Journal of Basic and Applied Pharmaceutical Sciences, Araraquara, v. 33, n. 1, p. 59-62, apr. 2012.

MATOS, F. J. A. Introduction to experimental phytochemical. 2 ed. Fortaleza: UFC, 1988. 141 p.

MOTT, J. D.; WERB, Z. Regulation of matrix biology by matrix metalloproteinases. Current Opinion in Cell Biology, Bethesda, v. 16, n. 5, p. 558-564, oct. 2004. http://dx.doi.org/10.1016/j.ceb.2004.07.010

NAGASE, H.; VISSE, R.; MURPHY, G. Structure and function of matrix metalloproteinases and TIMPs. Cardiovascular Research, Leuven, v. 69, n. 1, p. 562-573, jan.2006.

OSORIO, E. J.; ROBLEDO, S. M.; BASTIDA, J. Alkaloids with antiprotozoal activity. The Alkaloids: Chemistry and Biology, Amsterdam, v. 66, p. 113-190, jan. 2008. 
REIS, S. T.; LEITE, K. R. M.; PIOVESAN, L. F.; PONTES-JUNIOR, J. V.; NAYARA, I.; ABE, D. K.; CRIPPA, A.; MOURA, C. M.; ADONIAS, S. P.; SROUGI, M.; OGLIO, M. F. Increased expression of MMP-9 and IL-8 are correlated with poor prognosis of Bladder Cancer. Biomedical Urology, London, v. 12, n. 1, p. 12-18, jun. 2012.

RIBEIRO, R. I. M. A.; KURIBAYASHI, J. S.; BORGES, J. P. C.; BELETTI, M. E.; ESPINDOLA, F. S.; CASSALI, G. D.; LOYOLA, A. M. Inhibitions of Metalloproteinases by Aloe vera, Annona muricata, and black tea aqueous extracts. Bioscience Journal, Uberlândia, v. 26, n. 1, p. 121-127, Jan. 2010.

SENA FILHO, J. G.; MELO, J. G. S.; SARAIVA, A. M.; GONÇALVES, A. M.; PSIOTTANO, M. N. C.; XAVIER, H. S. Antimicrobial activity and phytochemical profile from the roots of Lippia alba (Mill.) N.E. Brown. Brasilian Journal Pharmacognosy, Curitiba, v. 16, n. 4, p. 506-509, Oct. 2006.

SILVA, M. D. Pharmacobotanical study of three species of medicinal caatinga in Pernambuco. 2008. 74f. Dissertation. (Master's degree in Botanic) - Post Graduate at Botany, Rural Federal University of Pernambuco, Recife, 2008.

VAID, M.; PRASAD, R.; SUN, Q.; KATIYAR, S. K. Silymarin targets $\beta$-catenin signaling in blocking migration/invasion of human melanoma cells. PLoS One, San Fracisco, v. 6, n. 7, p. 1-10, Jul. 2011.

WAGNER, H.; BLADT, S. Plant drug analysis. Thin Layer Chromatography Atlas. 2 ed. Springer. London. 2001. 369 p.

WALLARD, M. J.; PENNINGTON, C. J.; VEERAKUMARASIVAM, A.; BURTT, G.; MILLS, I. G.; WARREN, A.; LEUNG, H.Y.; MURPHY, G.; EDWARDS, D. R.; NEAL, D. E.; KELLY, J. D.

Comprehensive profiling and localisation of the matrix metalloproteinases in urothelial carcinoma. British Journal of Cancer, London, v. 27, n. 94, p. 569-577, Feb. 2006. http://dx.doi.org/10.1038/sj.bjc.6602931

WALTER, I.; HANDLER, J.; MILLER, I.; AURICH, C. Matrix metalloproteinase 2 (MMP-2) and tissue transglutaminase (TG 2) are expressed in periglandular fibrosis in horse mar with endometrosis. Histology and Histopathology, Murcia, v. 20, n. 4, p. 1105-1113, Oct. 2005. 